\title{
THE MANIFOLD EFFECTS OF THE MEDIONIGRA GENE OF THE MOTH PANAXIA DOMINULA AND THE MAINTEN- ANCE OF A POLYMORPHISM
}

\author{
P. M. SHEPPARD \\ Sub-Department of Genetics, The University, Liverpool \\ L. M. COOK \\ Department of Zoology, The University, Leicester
}

Received 8.i.62

\section{INTRODUCTION}

THE moth Panaxia dominula is a colony forming insect and in one population at Cothill near Oxford there is a unique polymorphism which has been studied intensively since 1939 (Fisher and Ford, 1947; Sheppard, I951, I953, I956). It results from the presence of a gene, called the medionigra gene, which in the homozygote produces form bimacula and in the heterozygote form medionigra. The polymorphism is unique in the sense that the gene is found in no other natural colony except as a very great rarity, or where deliberately introduced from Cothill.

The gene frequency at Cothill was about ro per cent. in 1939, although it had been much lower in the past, and the investigation was started to find out how important selection might be in determining changes in gene frequency from generation to generation. By 1947 it had been shown that the changes in gene frequency which had been observed since I 939 could not be ascribed to genetic drift (Fisher and Ford, 1947), and it was therefore pertinent to ask how natural selection was affecting the phenotypes concerned. However, by this time the gene had become sufficiently uncommon to make direct experiments and observations at Cothill difficult. Although the exact ecological conditions necessary for a population of $P$. dominula to survive are not known Kettlewell (1942) has defined the requirements sufficiently well for it to appear likely that places could be picked where moderately permanent artificial colonies could be established. It was therefore decided to try to establish such colonies with the medionigra gene at high frequency in order to study more easily the action of natural selection upon the three phenotypes dominula, medionigra and bimacula.

\section{THE ESTABLISHMENT OF ARTIFICIAL COLONIES}

(i) The Hinksey colony

The Oxford area was searched to find an ecologically suitable locality. A number of possible places were considered and investigated to make certain that the moth did not exist in them. Finally, one 
particular site was chosen because it was sufficiently isolated to preclude contamination from other colonies, and because the habitat was extremely unlikely to be disturbed by the reclamation of land for agricultural or building purposes. The locality is a valley about half a mile south of the village of North Hinksey. It is very steepsided, with a small stream at the bottom fed by numerous springs on the sides of the valley. Since the soil consists mainly of clay the ground is extremely wet, and the atmosphere is humid compared with that of the surrounding agricultural land. The northern slope is partly covered with an open wood of planted willows, Salix, whereas the south side is more open. In the wooded area much of the field layer vegetation consists of a dense mixture of Equisetum, hemp agrimony (Eupatorium cannabinum), willow-herb (Epilobiums pp.), and meadow-sweet (Filipendula ulmaria). There is also comfrey (Symphytum officinale), growing in the wettest places. On the south side there is a dense mass of the reed Phragmites communis high up on the side of the valley, which gives way to areas of the rush Juncus lower down. There are a large number of comfrey plants around the stream and in the less dense stands of Phragmites. There are also clumps of hawthorn bushes (Crataegus monogyna) and brambles, Rubus, near the stream, which become more numerous as one goes down the valley, finally developing into a dense scrub quite unsuitable for $P$. dominula. At the head of the valley there is a thick Phragmites marsh in which there is no Eupatorium, Filipendula or Symphytum, the three main food plants of the larvæ in this area. It restricts the extent of the colony, as does the agricultural land on either side of the valley.

In July $195 \mathrm{I}$ about 4000 fertile eggs from the backcross mating dominula $\times$ medionigra were scattered on the comfrey, both in the wooded area of the Hinksey valley and in the Phragmites. This mating ensured that the initial gene frequency was 25 per cent. In May 1952, 35 larvæ were obtained from the plants where the eggs had been scattered. Of the 30 moths that emerged only 9 were medionigra, showing a deficiency of the heterozygote $\left(\chi^{2}=4.0, P<0.05\right)$ and giving an estimated selective value for medionigra compared with dominula of 0.43 .

Although subsequently larvæ were seen in most years it was not until 1959 that they became sufficiently common for samples to be collected without fear of unduly diminishing the size of the population. From that year onwards the gene frequency in April has been obtained by collecting the larvæ, not more than two from each plant, raising them until they are adults, and then scoring the genotypes of the moths. It is known that in the laboratory there is no detectable differential elimination of the three genotypes, so that these estimates of genotype frequencies are not in any way biased. At Hinksey there has been an apparent drop in gene frequency between the $195^{2}$ sample and those of 1959 , r960 and 1961 combined (table 1 ). This change is not formally significant $\left(\chi_{\mathrm{I}}^{2}=3.80, \mathrm{P}>0.05\right)$. Because of 
the large sampling error involved, there is no evidence, therefore, as to whether the gene-frequency has been stable since 1952. However, since the change in gene frequency is in the same direction as that between $195^{1}$ and $195^{2}$ it seems likely that the change from a genefrequency of 25 per cent. to one of about 7 per cent. did not occur at one step between July 1951 and April 1952. It may even be that stability has not yet been established.

\section{(ii) The Genetic Garden colony at Oxford}

The Genetic Garden of the Department of Zoology at Oxford has an area of about Ioo square yards densely planted with comfrey. One end of the plot has twelve sallow bushes, Salix, planted in it with comfrey growing under them, the rest of the area being open. The soil is mostly gravel and the plot is bordered on two sides by an evergreen hedge. The area has laboratory buildings round it which give it protection from strong winds. Because of the well-drained

TABLE I

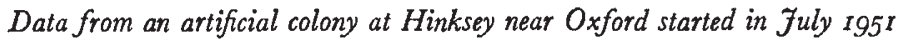

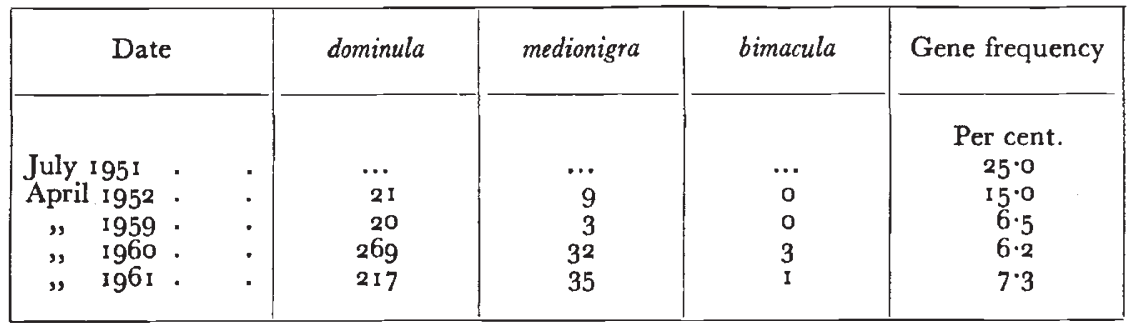

soil and the protection afforded by the hedge and buildings the garden is very dry and warm in sunny weather. In 1952 much of the comfrey in the plot was introduced by Dr H. B. D. Kettlewell from his garden at Cranleigh where there is an artificial colony of the moth. A number of larvæ must have been carried on these plants, because the year after introduction adults were seen on the wing. At least one of these was the homozygote bimacula. Samples have been taken from this population each year since 1958. The results are given in table 2. Here again there is evidence that the gene frequency has been dropping $\left(\mathrm{P}<0^{\circ} 02\right.$ for the regression). The reason for the high initial gene frequency is not known, but it might well be due to the very small size of the founder population which could have consisted of no more than two or three insects.

Thus, the two artificial colonies so far described have shown a reduction in the frequency of the medionigra gene, from an initial value of the order of 25 per cent.

\section{(iii) The Ness Garden colony}

In 1957 it was decided to start a new artificial colony in order to augment the data obtained in the 1951-52 experiment at Hinksey. 
The Botanical Garden at Ness, Cheshire, was selected because there was a suitable place available where an old cottage had been pulled down and its garden had been allowed to become overgrown. This locality had two important attributes, (I) being in a botanical garden the colony could be protected from interference, and (2) the moth is not known to be found within fifty miles of Ness so that there was no fear of contamination from wild populations. In the winter of $195^{8}$ some comfrey, an important food plant of the larvæ, was planted in the abandoned garden to supplement the supply of two other food plants, borage, Borago officinalis. and stinging nettle, Urtica dioica, which were already there. In the spring of $196 \mathrm{I}$, when the population had been established, more comfrey was planted as well as some hemp agrimony, a food plant both of the larvæ and of the adult moths. All the plants used were collected locally from road sides, railway banks and hedgerows, so that there was no possibility of introducing wild larvæ.

The area set aside for the colony is about one-third of an acre, together with about 50 yards of the banks of a sunken track which

TABLE 2

Data from the artificial colony in the Genetic Garden, Oxford

\begin{tabular}{|c|c|c|c|c|c|}
\hline & Date & dominula & medionigra & bimacula & Gene frequency \\
\hline $\begin{array}{l}1958 \\
1959 \\
1960 \\
1961\end{array}$ & . & $\begin{array}{l}24 \\
48 \\
21 \\
67\end{array}$ & $\begin{array}{r}13 \\
22 \\
8 \\
20\end{array}$ & $\begin{array}{l}4 \\
7 \\
1 \\
3\end{array}$ & $\begin{array}{c}\text { Per cent. } \\
25^{\circ} 6 \\
23.4 \\
16 \cdot 7 \\
14^{\circ} 4\end{array}$ \\
\hline
\end{tabular}

lies at one end. There are hawthorn hedges round most of the area and down both sides of the sunken track, and plants of borage growing in the hedges and on the banks. There is also a quantity of bramble, particularly along the track. At one end of the plot there are a number of evergreen oaks, Quercus ilex, and at the other end three large sycamore trees Acer pseudoplatanus. The area is divided into two by a tall hedge of privet, Ligustrum vulgare. A large number of comfrey plants have been put into the two areas separated by the hedge, but the one nearest the track which contains the sycamores is grassy whereas the other has brambles as well as a dense mass of stinging nettles and raspberry Rubus idaeus, growing in it. The soil is mostly clay which gets very damp in winter but becomes quite dry during fine weather in summer.

In order to study the selective value in the homozygote bimacula as well as the heterozygote medionigra it was planned to start the colony with a medionigra gene-frequency of 50 per cent. Consequently it was convenient to put out only heterozygotes in the first year and 
supplement with eggs from matings between heterozygotes the second year. This plan allowed the population to be augmented one year after its original release and had the added advantage that any modification of the ecology, such as that resulting from the larvæ eating the young shoots of the food plants in spring, would occur before differential selection could act, since in the first year all the larvæ were heterozygotes.

The original stock was derived from larvæ collected in the Genetic Garden at Oxford in the spring of 1958, and the eggs of 55 matings between bimacula and dominula were put down at Ness in late June I959. In June I96o medionigra from the same stock, and from larvæ taken at Hinksey, were mated and the fertile eggs from I4 such pairings were released. Consequently the expected frequency of dominula to medionigra to bimacula in I96I was I : 2 : I since all matings must have been between heterozygotes.

The population at Ness was sampled for about two hours each day in I96I from 28th June when the first adults were noticed, until 3oth July with the exception of Ist, I Ith, $24^{\text {th }}$ and $25^{\text {th }}$ July. No insect was seen after 22nd July. Thus it was sampled to about the same extent throughout the season except that a few insects may have been missed before 28th June. In all, 36 dominula, 42 medionigra and 2 I bimacula were captured. This ratio departs significantly from the expected I : 2 : I $\left(\chi_{2}^{2}=6.82, P<0.05\right)$. The results suggest that selection has been acting but it is possible that the discrepancy was caused by insects carrying the medionigra gene having tended to emerge earlier and having been missed before 28th June. This seems most unlikely since very few insects were seen flying in the first few days of collecting, so that sampling must have started soon after the first insects emerged. Moreover, extensive data from the wild population at Cothill have given no evidence that insects carrying the medionigra gene emerge earlier or later than do dominula (Sheppard, I956). However, the matter can be studied by testing for the effects of the gene on the date of first capture using the method described by Fisher and Ford (1947). Analysis of the Ness data reveals a significant difference between genotypes $\left(\chi_{\mathrm{r}}^{2}=4.64, \mathrm{P}<0.05\right)$. The mean day of first capture-fealling 28th June, day one) for dominula is 12.58 ; for medionigra it is 12.55 and for bimacula, I5.57, showing that the significance is due to the late emergence of bimacula. Since the gene frequency is low at Cothill, too few bimacula have been found there to allow such an effect to be detected.

These results at Ness also show that the departure from the expected I : 2 : I ratio is not due to incomplete sampling, since it is medionigra and bimacula which are deficient, but it is dominula not bimacula which would have been missing if the sampling did not start during the first few days of the emergence. Consequently the departure from the expected I : $2:$ I ratio demonstrates that selection must have been acting. It is possible, however, for selection to act without 
altering the gene-frequency. The estimated gene-frequency is $4^{2 \cdot} 4^{2} \pm 3^{\prime} 74$ per cent. Consequently the 95 per cent. confidence limits are $49^{\circ} 75$ to $35^{\circ}$ o9 per cent. which do not include the $5^{\circ}$ per cent. value. Thus, there is evidence not only from the departure from the expected I : 2: I ratio that selection is acting; but also, from the departure of the gene-frequency from the expected $5^{\circ}$ per cent., that it has decreased the frequency of the medionigra gene.

It is possible to calculate from these data the respective selective values of medionigra and bimacula compared to dominula. The value is $0.5^{8}$ in each case, but the two estimates are not wholly independent since they both involve a comparison with dominula. These results agree remarkably well with the value of 0.43 for medionigra estimated from the 1951-52 data obtained from the Hinksey colony, if it is remembered that very large sampling errors are involved. This is particularly interesting in view of the considerable difference in the ecology of the two populations. The results taken at their face value suggest that there is about $5^{\circ}$ per cent. selection against medionigra and probably bimacula during pre-adult life. Since at Ness all the parents were heterozygotes and at Hinksey all the matings were backcrosses to medionigra, this selection does not include any deleterious effects caused by the lower fertility of the medionigra and probably the bimacula males (see below).

\section{PLEIOTROPIC EFFECTS OF THE MEDIONIGRA GENE AND FACTORS WHICH INFLUENCE ITS FREQUENCY}

The medionigra gene was first recognised from the way that it affects the colour pattern of the wing. Several other associated characters have come to light in the present and earlier investigations.

\section{(i) Mating behaviour}

Sheppard (1952) showed that in the laboratory there is evidence of non-random mating between the genotypes, unlike genotypes tending to mate together. A small quantity of new data using stocks of different origin have been accumulated since then. These new data are not heterogeneous with those obtained earlier by Sheppard, and the combination of the two (table 3 ) increases the $\chi^{2}$ value (from $\chi_{x}^{2}=12.91$ to $\chi_{x}^{2}=14.12$ ), suggesting that non-random mating is not exclusively a property of the stock originally studied. It has not yet been possible to investigate mating preference in a colony, but this should be possible now that a number of artificial colonies with a high frequency of the medionigra gene have been established.

\section{(ii) Male fertility}

There is also additional evidence, obtained from stock derived from the Oxford Genetic Garden and Hinksey, upon the fertility of the various genotypes. Sheppard (1953) showed that there was no 
TABLE 3

\begin{tabular}{|c|c|c|c|c|}
\hline \multirow{2}{*}{\multicolumn{2}{|c|}{$\begin{array}{l}\text { Genotypes of the } \\
\text { three moths } \\
\text { in the cage }\end{array}$}} & \multicolumn{2}{|c|}{ Result of first mating } & \multirow{2}{*}{ Totals } \\
\hline & & $\begin{array}{l}\text { Like genotypes } \\
\text { pairing }\end{array}$ & $\begin{array}{c}\text { Unlike genotypes } \\
\text { pairing }\end{array}$ & \\
\hline & $\begin{array}{ll}\text { dominula } & \sigma^{*} \\
\text { dominula } & + \\
\text { medionigra } & +\end{array}$ & 14 & 32 & 46 \\
\hline 2 & $\begin{array}{l}\text { medionigra } \\
\text { dominula } \\
\text { medionigra } \\
+\end{array}$ & 12 & 14 & 26 \\
\hline 3 & $\begin{array}{l}\text { dominula } \sigma^{0} \\
\text { medionigra } \\
\text { medionigra } \\
+\end{array}$ & 14 & 15 & 29 \\
\hline & $\begin{array}{ll}\text { dominula } & \sigma^{*} \\
\text { medionigra } & \sigma^{*} \\
\text { dominula } & +\end{array}$ & 19 & 32 & $5^{1}$ \\
\hline 5 & $\begin{array}{l}\text { medionigra }{ }^{\hat{a}} \\
\text { medionigra } \\
\text { bimacula } \\
\end{array}$ & 3 & o & 3 \\
\hline 6 & $\begin{array}{ll}\text { bimacula } & \hat{0} \\
\text { medionigra } & \stackrel{+}{0} \\
\text { bimacula } & +\end{array}$ & 3 & 5 & 7 \\
\hline 7 & $\begin{array}{l}\text { medionigra } \\
\text { bimacula } \\
\text { bimacula } \\
\end{array}$ & 3 & 15 & 18 \\
\hline & $\begin{array}{l}\text { medionigra } 0 \\
\text { bimacula o } \\
\text { medionigra } \\
\stackrel{+}{+}\end{array}$ & 3 & 12 & 15 \\
\hline 9 & 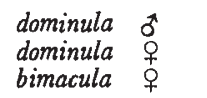 & 3 & I & 4 \\
\hline & Totals . & 73 & 126 & I99 \\
\hline
\end{tabular}


detectable difference in the number of eggs laid by females of the three genotypes, but that there was a just significant increase in infertility in medionigra males as compared with dominula males, $\left(\chi_{\mathrm{I}}^{2}=6.27, \mathrm{P}<0^{\cdot 02}\right)$. The new data are in agreement with this result, increasing the significance of the difference between the fertility of dominula and medionigra males $\left(\chi_{\mathrm{I}}^{2}=\mathrm{I} 2.90, \mathrm{P}<0.00 \mathrm{I}\right)$ (table 4$)$, so that the conclusion that medionigra males are considerably less fertile than dominula males can be in no doubt. Their fertility is probably reduced to about 75 per cent. of that of the dominula males. The bimacula males also appear to be less fertile, but the data are insufficient to demonstrate this conclusively.

TABLE 4

\begin{tabular}{|c|c|c|c|c|}
\hline Mating & & Fertile & Infertile & $\begin{array}{l}\text { Per cent. } \\
\text { infertile }\end{array}$ \\
\hline $\begin{array}{l}\text { dominula } \sigma \times \text { dominula }+ \\
\text { dominula } \bar{\sigma} \times \text { medionigra } \\
\text { dominula } \\
\text { ơ } \times \text { bimacula }\end{array}$ & $: \quad:$ & $\begin{array}{r}35 \\
45 \\
I\end{array}$ & $\begin{array}{l}4 \\
7 \\
0\end{array}$ & $12 \cdot 0$ \\
\hline $\begin{array}{l}\text { medionigra } \sigma^{*} \times \text { dominula }{ }^{\circ} \\
\text { medionigra }{ }^{*} \times \text { medionigra } \\
\text { medionigra }{ }^{ \pm} \times \text {bimacula }{ }^{+}\end{array}$ & : $\quad:$ & $\begin{array}{l}34 \\
24 \\
11\end{array}$ & $\begin{array}{r}13 \\
16 \\
8\end{array}$ & 34.9 \\
\hline 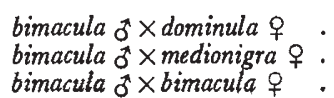 & $: \quad:$ & $\begin{array}{l}\text { I } \\
8 \\
3\end{array}$ & $\begin{array}{l}0 \\
3 \\
2\end{array}$ & 29.4 \\
\hline
\end{tabular}

\section{(iii) Female fertility}

If one examines the proportions of infertile matings among the females of different genotypes taking into account the differential fertility of the males, one observes a tendency for medionigra females to be less fertile than dominula females but more so than bimacula females. However, this effect, although sufficiently marked to merit further investigation, is in no way significant as it stands.

\section{(iv) Date of emergence}

In the Ness colony it has been shown that the homozygote bimacula tends to emerge later than the other forms. This may also lead to slight selection against the medionigra gene, since males tend to emerge earlier than females (Sheppard, I95I) so that some of the late bimacula may not be mated.

\section{(v) Viability between egg and adult}

The data for the first generation of the Hinksey colony showed that there had been selection against medionigra during the egg and/or 
larval stage, while the results from Ness have demonstrated selection against medionigra and/or bimacula at some time between the egg and adult. The elimination in these two colonies has been such as to indicate about $5^{\circ}$ per cent. selection against carriers of the mutant gene. This value is probably somewhat variable in the wild since no differential mortality is observed in the laboratory, indicating that the environment can have a marked effect on the relative selective values of the genotypes.

\section{DISCUSSION}

The three artificial colonies have all shown over a period of years a reduction in the frequency of the medionigra gene from an initial high frequency. While the decline was being observed abundant evidence has also been collected attesting to the selective disadvantage of the gene, so that it is a germane question at this stage to ask whether these selective effects will account for the changes in gene frequency in the wild colony at Cothill.

Examination of the records from Cothill shows that there was an initial reduction in gene-frequency from the time when it was first studied until about 195I. Thereafter the frequencies fluctuated significantly $\left(\chi_{9}^{2}=54.4 \mathrm{I}, \mathrm{P}<0.00 \mathrm{I}\right)$ about an average of 3 per cent. and have shown no consistent trend except possibly from 1957 until 1961 , when gene frequency has shown signs of dropping rather rapidly. If the frequencies are transformed to logarithms the regression of gene frequencies on year at Cothill can be calculated for the years 1939 to 195 I inclusive, since it was not until 1952 that a significant departure from a straight line regression was detected (Sheppard, 1953). A comparison of the slopes of the regression lines for the artificial colonies with that from Cothill shows that the Cothill slope tends to be shallower; although the difference is not significant possibly because there are as yet too few points.

Calculation shows that the infertility of the medionigra males alone can account adequately for the speed at which the gene decreased in frequency at Cothill, as well as in the Hinksey colony between 1952 and 1961 . It seems likely that the medionigra males are relatively infertile at Cothill as they are in the laboratory at the present time; and it also appears probable that the elimination between egg and adult operates there in view of the fact that it occurs in the Ness and Hinksey colonies which differ so widely in their ecology. But fluctuations in gene frequency at Cothill and the absence of any marked trend since 195 I cannot be due to those effects of the gene on fertility and viability which have been so far considered since they are all disadvantageous. It is therefore reasonable to suppose that some counter-selection is operating to hold the gene-frequency stable in the region of 2-3 per cent. This view is further strengthened by an experiment at Sheepstead Hurst (Sheppard, 1956) where the medionigra gene was introduced in 1954 at a frequency of approximately 
0.2 per cent., and by I 96 I had reached a frequency of about I.o per cent. suggesting that the gene is at an advantage when at very low frequency, but at a disadvantage when at a high frequency (table 5). Since the insects carrying the medionigra gene, whether they be heterozygotes or homozygotes, appear to be at a disadvantage between the egg and adult stages, any compensating selection is likely to operate in the adult alone. It has been apparent for some time that the selective value of the homozygote bimacula cannot be of much importance in maintaining the equilibrium at Cothill since this genotype is so rare. It therefore seems likely that the selective advantage of the medionigra adult moth increases with decreasing gene-frequency until its advantage counteracts the disadvantage due to the lowered fertility of the males and the inviability between egg and adult. Sheppard ( 1953 ) had already noted that at low gene-frequencies the medionigra males will tend to mate with relatively more females than will the

TABLE 5

Data obtained after introduction of the gene to the Sheepstead Hurst colony

\begin{tabular}{|c|c|c|c|}
\hline Date & dominula & medionigra & $\begin{array}{c}\text { Gene-frequency } \\
\text { per cent. }\end{array}$ \\
\hline $\begin{array}{l}1954 \\
1955 \\
1956 \\
1961\end{array}$ & $\begin{array}{c}\text { eggs from } 50 \\
873 \\
443 \\
405\end{array}$ & $\begin{array}{c}\text { gotes released } \\
2 \\
4 \\
9\end{array}$ & $\begin{array}{l}0.2 \text { approx. } \\
0.1 \\
0.4 \\
I .1\end{array}$ \\
\hline
\end{tabular}

dominula males if there is disassortative mating, since the male can mate several times but the female only once. Williamson (I96o) has pointed out that this is the sole effect of the gene so far detected which could account for the change in selective value. Data on the frequency of medionigra amongst copulating moths found at Cothill is consistent with the hypothesis that the male is more likely to find a mate than the dominula male, but quite inadequate at the moment to prove or disprove it, while the laboratory breeding experiments have not as yet shown that the mating preference is sufficiently pronounced to maintain the polymorphism.

Provided disassortative mating acts in the wild and is sufficiently pronounced the selective forces which have been detected are such that a stable equilibrium could be established which is not dependent on the selective superiority of the heterozygotes, as Williamson (rg6o) has pointed out. These selective forces, if constant, do not account for the increase in the frequency of medionigra at Cothill between I929 and I939 or the yearly fluctuations in gene frequency between I 95 I and I96I, but two points may usefully be made which bear on the situation:

(a) Since the differential elimination between egg and adult does 
not appear in laboratory broods, it may be inferred that this disadvantage of the medionigra and bimacula forms is likely to be subject to some fluctuations as a result of the varying influence of the wild environment. As yet the experiments with artificial colonies are not sufficiently numerous to detect such an effect in nature.

(b) It seems likely that weather conditions, because they will affect population size as well as the length of the emergence period, and thus the ratio of males to virgin females, will modify the selective advantage of medionigra males in the wild by influencing the degree of disassortative mating.

Thus selection acting on the known pleiotropic effects of the gene could account for the observed changes in gene-frequency at Cothill, provided we admit that disassortative mating and the selection so generated, together with that operating between egg and adult, can fluctuate from year to year with changes in the environment. This does not mean that the manifold effects of the gene detected so far are all those that are acting. It may be that there are still others whose selective values are more markedly influenced by the environment.

In order to explore further the possible significance of non-random mating it is planned to release known proportions of males of the three genotypes at various densities, then to put out a number of virgin females and note the genotypes of the copulating pairs. Repetition of such experiments should produce comparative data, allowing one to determine the extent to which mating behaviour can be important in maintaining the polymorphism at Cothill, and in controlling the fluctuations in gene-frequency from year to year.

\section{SUMMARY}

I. The polymorphism present in the colony of the moth Panaxia dominula at Cothill, near Oxford, is controlled by a pair of allelomorphs. The typical homozygote dominula, the heterozygote medionigra and the rare homozygote bimacula are distinguishable from each other on their wing colour patterns.

2. In order to study the selective advantages of the three genotypes two artificial colonies were founded, one at Hinksey near Oxford, the other at Ness, Cheshire. A third colony which started as a result of the accidental importation of larvæ was also studied in a garden near the Department of Zoology at Oxford. In all three colonies the frequency of the medionigra gene fell rapidly, changing from the initial value of 25 per cent. to about 7 per cent. at Hinksey between I95I and I96I, from about 25 per cent. to about 14 per cent. at the Department of Zoology between $195^{8}$ to $196 \mathrm{I}$, and from $5^{\circ}$ per cent. at Ness to about 43 per cent. between 196o and 196r. Part of this disadvantage was due to lowered viability of medionigra and probably of bimacula between egg and adult. This disadvantage of the heterozygote compared with the wild type dominula is estimated to have been about $5^{\circ}$ per cent. in these artificial colonies. 
3. The gene was also introduced into a natural colony near Oxford and increased from an initial frequency of about 0.02 per cent. in 1954, to about I per cent. in 196I. This suggests that the gene can form a stable polymorphism, being advantageous when rare, disadvantageous when common.

4. Studies in the laboratory have shown that there is disassortative mating between the genotypes and that the medionigra males are less fertile than the dominula males. It is suggested that the disadvantage of carrying the medionigra gene, due to lowered viability and the lowered fertility of the males, is counterbalanced by the advantage due to disassortative mating when the gene-frequency is low. This situation could give a stable polymorphism, a decrease in the frequency of the gene in the artificial colonies, stability at Cothill and an increase in frequency when introduced at very low value in a natural colony.

5. It is pointed out that the fluctuations in gene-frequency observed in the natural colony at Cothill could be due to slight changes in the selective values of the genotypes as a result of varying environmental conditions from year to year.

Acknowledgments.-We are extremely grateful to Dr E. B. Ford, F.R.s. for his encouragement and for his detailed comments on the manuscript. We should also like to express our indebtedness to Dr A. J. Cain, Dr C. A. Clarke, Mr E. R. Creed, Dr H. B. D. Kettlewell and Dr M. H. Williamson for their helpful criticisms of the manuscript. One of us (P.M. S.) would like to thank the Nuffield Foundation for their continued support.

\section{REFERENCES}

FISHER, R. A., AND FORD, E. B. 1947. The spread of a gene in natural conditions in a colony of the moth Panaxia dominula L. Heredity, I, I43-I 74 .

Kettlewell, H. B. D. 1942. A survey of the insect Panaxia (Callimorpha) dominula L. Proc. S. London Entomol. Nat. Hist. Soc., I -49.

SHEPPARD, P. M. I95I. A quantitative study of two populations of the moth Panaxia dominula (L.). Heredity, 5, 349-378.

SHEPPARD, P. M. 1952. A note on non-random mating in the moth $P$. dominula. Heredity, 6, 239-24I.

SHEPPARD, P. M. 1953. Polymorphism and population studies. Symposia Soc. Exptl. Biol. No. 7, 274-289.

SHEPPARD, P. M. 1956. Ecology and its bearing on population genetics. Proc. Roy. Soc. $B, 145,308-315$.

williamson, м. H. 1960. On the polymorphism of the moth Panaxia dominula (L.). Heredity, 15, 139-I5I. 